\title{
Cele ideowe i struktura organizacyjna Wszechzwiązkowej Organizacji Pionierskiej imienia W.I. Lenina oraz jej miejsce w systemie wychowanie nowego czlowieka (homo sovieticus)
}

\begin{abstract}
The ideological aims and organisational structure of the Vladimir Lenin All-Union Pioneer Organisation and its place in the system of education of a new man (homo sovieticus)

One of the characteristics of the second half of the 19th and 20th centuries was the tendency of young people to gather in youth associations and organisations. Some of these were created spontaneously and their activities were illegal, while others were created by the authorities of particular states, especially totalitarian ones. One example of such an organisation was the AllUnion Pioneer Organisation, established by the leaders of the Bolshevik Revolution in Russia in 1922. Its strategic goal was to participate in the education of the new man, who was to become homo sovieticus, a higher variety of homo sapiens, in the future. The Pioneer Organisation fulfilled this task by organising children of school age (aged 9 to 14) and subjecting them to a systematic ideological and political training based on the Leninist or Stalinist model. The activities of the Pioneer Organisation were supervised by the Komsomol and additionally by the leadership of the communist party ruling the USSR. The structure of the Pioneer Organisation included groups, packs and cells. Like the Komsomol, the Pioneer Organisation also had its symbols, such as the threepointed red scarf that symbolised three generations: communists, komsomolets and pioneers, as well as a pioneer badge, a pioneer salute, a uniform, bugles and a snare drum.
\end{abstract}

Keywords: Pioneer Organisation, Komsomol, Soviet Russia, new man, homo sovieticus, indoctrination, pioneer

\section{Geneza i założenia koncepcji nowego człowieka w Rosji}

Mając na uwadze stan badań nad wychowaniem młodych pokoleń w warunkach państwa autorytarnego, warto raz jeszcze przybliżyć zarówno idę̨ wychowania nowego człowieka (homo sovieticus), jak i założenia organizacyjne i pedagogiczne, poczynione 
przez władze Rosji sowieckiej z myślą o urzeczywistnianiu założeń tego szczególnego ideału wychowawczego ${ }^{1}$. Uzasadniona zatem wydaje się również analiza podstaw programowych Organizacji Pionierskiej (Wszechzwiązkowej Organizacji Pionierskiej imienia W.I. Lenina), ideowej przybudówki Komsomołu i swoistego przedszkola wychowania komunistycznego w ZSRR. Zadanie to wydaje się tym bardziej zasadne, że doświadczenia Rosji sowieckiej po roku 1945 stały się wzorem i szczególnym punktem odniesienia dla poczynań władz komunistycznych w Polsce, dążących do stworzenia rodzimej wersji modelu wychowania komunistycznego dzieci i młodzieży ${ }^{2}$. Za podjęciem wątku badawczego skupionego na idei wychowania nowego człowieka przemawia też fakt, że określenie homo sovieticus weszło do języka polskiego co najmniej kilkanaście lat temu i jest bardzo różnie, zazwyczaj nieadekwatnie, rozumiane.

Realizację tak zarysowanego celu badań, należy rozpocząć od przypomnienia, że włączenie w roku 1945 Polski i innych państw Europy Środkowej w orbitę wpływów Związku Radzieckiego oznaczało nie tylko ograniczenie ich suwerenności państwowej i zniewolenie polityczne, ale także narzucenie tym krajom szczególnego modelu państwa - państwa sowieckiego opartego na kłamstwie. Tę szczególną cechę ZSRR uwypuklił już w latach 30. XX w. jeden z sowietologów, stwierdzając: ZSRS to kraj kłamstwa, kłamstwa absolutnego, kłamstwa integralnego $[\ldots]^{3}$. Kraj, w którym obowiązuje zasada: gdy wszyscy kłamia - to nikt nie kłamie, kiedy kłamie [...] Każdy artykut konstytucji zawiera wielopiętrowe oszustwa [...]. Prawa narodów, demokracja, prawa konstytucyjne: jedno wielkie kłamstwo [...]. Dowody: kłamstwo. Fotografie: kłamstwo. Świadkowie i ich zeznania: kłamstwo. Zebrania, zjazdy: reżyserowane przedstawienia. Dyktatura proletariatu: monstrualne oszustwo. Entuzjazm mas: drobiazgowa organizacja [...]. Radosne życie: ponura farsa [...]. Kultura: prostactwo. Genialny wódz: zaślepiony despota [... $]^{4}$.

Funkcjonowanie tak zorganizowanego państwa wymagało daleko idących zmian w świadomości jego obywateli. Pociągało też za sobą potrzebę stworzenia nowego społeczeństwa, złożonego z ludzi zniewolonych i zastraszonych, którzy państwo komunistyczne (oparte na kłamstwie i terrorze) gotowi byliby nie tylko akceptować, ale wręcz się z nim utożsamiać. Stąd też przywódcy zwycięskiej rewolucji bolszewickiej w Rosji w 1917 r. nie zadowolili się przejęciem władzy w kraju. Ich kolejnym strategicznym celem stało się stworzenia nowego człowieka - homo sovieticus - istoty, która miała być udoskonaloną formą homo sapiens ${ }^{5}$. Warunkiem realizacji ostatniego z wymienionych

${ }^{1}$ Na gruncie nauki polskiej pogłębioną analizę ideału nowego człowieka (homo sovieticus) przeprowadził m.in. M. Mazur w pracy pt. O człowieku tendencyjnym... Obraz nowego człowieka w propagandzie komunistycznej w okresie Polski Ludowej i PRL 1944-1956, Wyd. UMCS, Lublin 2010.

2 Por. m.in. R. Grzybowski, U podstaw ksztaltowania się totalitarnego systemu wychowania i opieki nad dzieckiem i rodzina $w$ Polsce $w$ latach 1945-1956, „Studia i Badania Naukowe. Pedagogika” R. II, nr 2/, Gdańsk 2008, s. 233-253.

${ }^{3}$ B. Souvarine, Aveux a Moscou, „La Vie Intelectuelle”, Paryż 10.04.1038. Cyt. Za: M. Heller, A. Niekricz, Utopia władzy. Historia Związu Sowieckiego. Od narodzin do wielkości 1917-1939, Wyd. Zysk S-ka, Poznań 2016, s. 13.

4 Ibidem, s. 13.

${ }^{5}$ M. Heller, Maszyna i śrubki. Jak hartowat się człowiek sowiecki, Instytut Literacki, Paryż 1988, s. 9. 
celów stało się włączenie nie tylko szkoły, ale całego systemu wychowanie młodego pokolenia w struktury totalitarnego państwa. Stan ten stanowił odzwierciedlenie specyfiki państwa sowieckiego, charakteryzującego się totalnym oddziaływaniem rządzącej partii na wszystkie sfery życia w skali, jakiej nie znał dotąd świat. Sytuacja ta, jak zauważa Michał Heller, zdeterminowała charakter wszystkich sowieckich instytucji [...]. Ten totalny nacisk zdeformowat przebieg normalnych procesów, właściwych współczesnemu społeczeństwu i doprowadzit do wykształcenia nowej, nieznanej dotąd formy społeczeństwa i państwa ${ }^{6}$. Zapoczątkował też historię homo sovieticus.

W kontekście powyższych stwierdzeń warto przypomnieć zasadnicze etapy procesu kształtowania się idei homo sovieticus. Sama koncepcja „nowego człowieka” zrodziła się bowiem w latach 60. XIX w. w kręgach radykalnej, rosyjskiej młodzieży studenckiej, zgrupowanej w Centralnym Komitecie Rewolucyjnym. Opracował ją Piotr Tkaczow, który scharakteryzował człowieka przyszłości jako nowy, wyższy typ człowieka rewolucjonisty, przeciwieństwo mieszczucha (człowieka niższego typu). Celem życia człowieka miało być dążenie do zapewnienia szczęścia większości ludzi ${ }^{7}$. Pogłębienie koncepcji nowego człowieka, zarysowanej przez P. Tkaczowa, przyniósł wydany w roku 1868 Katechizm rewolucjonisty, programowy dokument tajnego sprzysiężenia „Narodnaja Sprawa"8. Nowy człowiek, sportretowany we wspomnianym dokumencie, to zawodowy rewolucjonista, człowiek stracony dla świata, nie posiadający ani własnych interesów, ani spraw, ani uczuć. To człowiek pozbawiony własności prywatnej, a niekiedy nawet imienia, w całości podporządkowany jedynemu celowi, jedynej namiętności, którą była rewolucja ${ }^{9}$, ktoś, kto gardzi opinią publiczną, nienawidzi wszelkich przejawów moralności publicznej. Moralne jest wszystko, co sprzyja zwycięstwu rewolucji, niemoralne $i$ przestępcze wszystko, co jej staje na drodze ${ }^{10}$. Rewolucjonista (nowy czlowiek) powinien być surowy zarówno wobec siebie, jak i wobec innych. Winien też zdusić w sobie wszelkie uczucia przyjaźni, miłości, wdzięczności, a nawet honoru, podobnie jak uczucia powstająca na bazie pokrewieństwa. Ich miejsce miała zająć chłodna namiętność dla sprawy rewolucji.

Ucieleśnieniem nowego człowieka - rewolucjonisty stał się Rachmietow, bohater (opublikowanej w roku 1863) powieści N. G. Czernyszewskiego Co robić? Opowieści o nowych ludziach ${ }^{11}$. Wspomniany Rachmietow to człowiek żyjący tylko dla rewolucji, wyrzekający się rodziców, przyjaciół i kobiet. Charakteryzowało go wysokie mniemanie o sobie, a także poczucie, że jest potrzebny rewolucji. To dlatego uprawiał sport, ćwiczył

\footnotetext{
${ }^{6}$ M. Heller, A. Niekricz, Utopia władzy. Historia Związu Sowieckiego. Od narodzin do wielkości..., s. 23 .

${ }^{7}$ Z tej populacji P. Tkaczow wyłączył jednak wrogów, do których gotów był zaliczyć każdego, kto w jakikolwiek sposób wzbudzi uczucie niezgodne z ideałem ludzkiego szczęścia. Ibidem, s. 17.

${ }^{8}$ Katechizm rewolucjonisty wiązany jest z nazwiskiem Siergieja Nieczajewa, ale jego autorstwo nie zostało ostatecznie ustalone. Por. M. Heller, op. cit., s. 18. Wspomniany M. Heller określa go jako najbardziej radykalny projekt nowego człowieka.

${ }^{9}$ M. Heller, op. cit., s. 19.

10 Ibidem, s. 19.

${ }^{11}$ N. G. Czernyszewski, Szto diełat?, Moskwa 1970.
} 
intelekt lekturą odpowiednich książek, kształtował charakter, śpiąc na gwoździach. W życiu osobistym cechował go swoisty ascetyzm - żadnego zbytku w jedzeniu, żadnego wydawania pieniędzy na produkty, bez których można się obejść.

Do ideału nowego człowieka nawiązał Włodzimierz Lenin ${ }^{12}$, który teorię rewolucji społecznej łączył z koncepcją człowieka uwikłanego w określone stosunki społeczne. Nowy człowiek w jego poglądach przybrał postać bojownika komunizmu - jednostki uspołecznionej, zdolnej do działania na rzecz dobra wspólnego (rozumianego jednak bardzo szeroko - w skali całego społeczeństwa) ${ }^{13}$. Fundamentalną cechą bojownika komunizmu miało być głębokie zaangażowanie społeczne i czynna postawa w walce o sprawiedliwość i postęp W obszarze współżycia zbiorowego ${ }^{14}$. Do tego dochodziła świadoma dyscyplina, nienawiść do dawnego społeczeństwa (łącząca się z gotowością i umiejętnością zjednoczenia i zorganizowania sił do walki) oraz skłonność do pracy dla dobra swego kraju ${ }^{15}$.

Idea nowego człowieka, urzeczywistniania w Rosji bolszewickiej od pierwszych miesięcy po zwycięskiej rewolucji, nieustannie ewoluowała. Punktem wyjścia dla niej stał się wspomniany, leninowski model bojownika komunizmu - rewolucjonisty, burzyciela starego porządku. Jego ucieleśnieniem byli niezłomni jak żelazo komisarze oraz twardzi jak stal czekiści ${ }^{16}$. W kolejnej fazie rozwoju ZSRR dominował model budowniczego nowego ładu, występujący w wariantach: człowieka przemysłowego, człowieka naukowo-organizacyjnego oraz udoskonalonego komunistycznego czlowieka, charakteryzującego się ideowością, energią oraz inicjatywą.

Według Stalina najpełniejszym odzwierciedleniem człowieka sowieckiego była śrubka: w tym ujęciu nowy człowiek sowiecki miał się uważać za śrubkę w wielkiej machinie państwowej. Z kolei następca Stalina, Nikita Chruszczow, był przekonany, że w ramach kształtowania nowego człowieka należy stworzyć śrubkę łączącą nieugiętość ideową z rozległym wykształceniem, moralną czystością i fizyczną doskonałością ${ }^{17}$. Niezależnie od fazy kształtowania nowego człowieka w ZSRR, każdy z wymienionych modeli powinien uwzględniać poczucie przynależności do państwa oraz do kolektywu. Nowy człowiek sowiecki miał też mieć pełną świadomość tego, że on sam - jako jednostka - nie znaczy nic wobec państwa ${ }^{18}$.

12 T. Wiloch, System wychowawczy a socjalizm w ujęciu Lenina, „Nauczyciel i Wychowanie” 1970, nr 2(64), s. 17-20.

${ }_{13}$ H. Muszyński, Poglądy Lenina na wychowanie i ich znaczenie dla rozwoju socjalistycznej pedagogiki, „Nauczyciel i Wychowanie” 1970, nr 3/65, s. 28.

14 Ibidem, s. 33.

${ }^{15}$ W. Lenin, Zadania związków młodzieży. Przemówienie wygłoszone na III Ogólnorosyjskim Zjeździe Komunistycznego Związu Młodzieży Rosji, 2 października 1920 roku, w: Źródła do dziejów wychowania i myśli pedagogicznej, t. III, Warszawa 1965, s. 534-535.

16 Ibidem, s. 12.

17 „Prawda” z 18 października 1961 r. Omawiam za: M. Heller, op. cit., s. 12.

${ }^{18}$ Czyż nie jest jasne, że przypuszczać, iż „ja” może mieć jakieś prawa $w$ obliczu państwa to tyle samo, co przypuścić, że gram może zrównoważyć tonę? Stąd i podziat: tona ma prawa, gram obowiąki; $i$ naturalna droga od nicości do wielkości: zapomnij, żeś gramem i poczuj się milionową częścia tony. Cyt. za: M. Heller, op. cit., s. 12. 
Ostateczny wariant nowego człowieka sowieckiego (homo sovieticus) ukształtował się w drugiej połowie XX w. Wśród jego cech na plan pierwszy wysuwały się takie dyspozycje osobowościowe, jak komunistyczna ideowość i partyjność (wyrażająca się w jego światopoglądzie i podejściu do ideałów komunizmu). Człowiek sowiecki określany był też jako człowiek pracy, bezgranicznie oddany socjalistycznej, wielonarodowościowej ojczyźnie; człowiek kolektywu, charakteryzujący się poczuciem odpowiedzialności za wszystko, co się w ZSRR działo, zaangażowany zarówno w sprawy międzynarodowe, jak i codzienne życie sąsiadów. Spostrzegano go też jako człowieka wyższych ideałów, aktywnie wcielającego w życie program Rewolucji Październikowej, harmonijnie rozwijającego się, a przy tym szczęśliwego. Homo sovieticus miał bowiem żywić przeświadczenie, że komunistyczne państwo się o niego troszczy, wyrazem czego był rozwój komunistycznej ojczyzny (ZSRR). Inną ze znaczących cech homo sovieticus było pełne zaufanie do kierownictwa partii i władz państwa, które - jak wierzył - sprawują władzę $\mathrm{w}$ jego imieniu i jego interesie ${ }^{19}$. Ponadto był on przyuczony do życia $w[\ldots]$ trudnych warunkach, gotów stawiać czoła trudnościom [...], spodziewał się jeszcze gorszych czasów, pochwalat działania władz, starat się przeszkadzać tym, którzy naruszali utarte normy postepowania, cała dusza popierat kierownictwo, miat standardowa zideologizowana świadomość i poczucie odpowiedzialności za kraj, gotów byt ponosić ofiary oraz poświęcić innych $w$ ofierze $e^{20}$.

Warto podkreślić, że rozciągnięty w czasie proces formowania założeń homo sovieticus bazował na założeniu, że każde z kolejnych pokoleń będzie traktować zastane warunki jako normę ${ }^{21}$. Nie będzie się zatem przeciwko nim buntować ani też ich rewidować, ponieważ jedyne, co może wybrać, to doskonalenie systemu. Do tego zadania dzieci i młodzież były przygotowywane w ZSRR w procesie intensywnego, totalnego urabiania. Szczególnego znaczenia nabierało tu traktowane priorytetowo wychowanie w duchu moralności komunistycznej22.

\section{Tresura jako sprawdzony mechanizm ksztaltowania nowego czlowieka}

Mając świadomość, że dalsze losy rewolucji zależa [...] od tego, jak dalece uda się [...] przekształcić młode pokolenie $w$ materiat ludzki, zdolny do budowy socjalistycznej gospodarki społeczeństwa komunistycznego ${ }^{23}$, komunistyczne władze ZSRR podjęły działania zmierzające do stworzenia spójnego systemu instytucji oraz doboru metod gwarantujących skuteczną indoktrynację sowieckich dzieci i młodzieży. Po okresie poszuki-

19 Sowietskije ludi, praca zbior., Moskwa 1974, s. 4-5. Omawiam za: M. Heller, op. cit., s. 27-28.

${ }^{20}$ A, Zinowiew, Homo sovieticus, Lozanna. 1982. Omawiam za: M. Heller, op. cit., s. 28.

${ }^{21}$ Ibidem, s. 29.

${ }^{22}$ R. Grzybowski, O wychowaniu w duchu moralności komunistycznej w ujęciu pedagogiki stalinowskiej oraz o niektórych metodach jej realizacji, w: Człowiek Idea Dzieło. Prace dedykowane Profesor Stefanii Walasek, red. B. Jędrychowska, Wydawnictwo Chronicon, Wrocław 2013, s. 211-229.

${ }^{23}$ M. Heller, op. cit., s. 148. 
wań (m.in. z udziałem pedologów ${ }^{24}$ ), u progu lat 30. XX w. uznały one, że najbardziej efektywną metodą, którą należy zastosować w procesie wychowania nowego człowieka (homo sovieticus) będzie metoda treningu, określana też mianem systemu tresury ${ }^{25}$.

Metoda treningu (tresury) wymagała $\mathrm{z}$ jednej strony systematycznego powtarzania tych samych gestów i słów, z drugiej zaś nieustannego przywoływania do świadomości postaci wodza (do połowy lat 50. XX w. Stalina, po tym okresie głównie Lenina). Krytycy wychowania sowieckiego mówią w związku z tym o pokoleniach ,wytresowanych" na modelu Stalina, bądź Lenina. Twórcy systemu konsekwentnie zadbali też o to, by postać wodza (na przykład jego portret) towarzyszyła dziecku od pierwszych dni życia. Słowo „Lenin” miało być też pierwszym, które dziecko rozpoczynające naukę w szkole powinno przeczytać w swym elementarzu ${ }^{26}$. Odwołania do modelu (wodza) miały towarzyszyć dziecku zarówno w trakcie nauki szkolnej, jak i poza szkołą, w tym zwłaszcza w strukturach organizacji dziecięcej i młodzieżowej27.

Realizacja tak ujętego celu wymagała zapewnienia sobie przez władze komunistyczne monopolu w zakresie wychowawczego oddziaływania na dzieci i młodzież. W praktyce oznaczało to dążenie do rozbicia tradycyjnej rodziny ${ }^{28}$, a także całkowitego odsunięcia Kościoła od wychowania dzieci i młodzieży ${ }^{29}$. Działania te doprowadziły do zaniku tradycyjnych autorytetów. W rezultacie życie społeczne Rosji bolszewickiej w pierwszych dziesięcioleciach rozwijało w swoistej próżni aksjologicznej, co prowadziło do różnorodnych wynaturzeń typu idea wolnej miłości i pełnej swobody seksualnej. Dobrze ilustruje to wypowiedź starego bolszewika, cytowana przez jedno z ówczesnych czasopism sowieckich: Autorytet rodziców? - nie istnieje; autorytet wiary? - nie istnieje; tradycja? - nie istnieje, poczucie moralności? Stara moralność umarła, a nowa się jeszcze nie narodziła ${ }^{30}$.

${ }^{24}$ Odwrót od łagodnej postaci „obróbki materiału ludzkiego”, polegającej na założeniu, że zmiana warunków politycznych, materialnych i społecznych w ZSRR pociągnie za sobą zmiany w mentalności człowieka, nastąpił w połowie lat trzydziestych.

${ }_{25}$ Zdaniem sowietologów, o narodzinach systemu tresury, określanego też metoda hipnotyczego, terrorystycznego nacisku na dzieci, zadecydowało m.in. odejście kierownictwa partii z J. Stalinem na czele od ideologii rozumianej jako zbiór poglądów oraz rezygnacja z wiary wychowanków w dogmaty leżące u podstaw ideologii komunistycznej. W ich miejsce zaszczepiano w świadomości ludzi sowieckich bezrefleksyjną wiarę w hasła i treści przekazywane przez kierownictwo partii oraz kult wodza (przywódcy państwa sowieckiego), który w systemie treningu (tresury) stał się najwyższym, niezawodnym autorytetem i modelem - źródłem wartości i wzorów zachowań. Por.: A. Załkind, Pedologia w SSSR, Moskwa 1929. Cyt. za: M. Heller, op. cit., s. 154.

${ }^{26}$ M. Heller, op. cit., s. 155.

27 Odnosi się to także do wychowania w przedszkolu, organizowanego w warunkach polskich w latach stalinowskich. Por. m.in.: R. Grzybowski, Podmiot czy tworzywo? Kilka uwag o sytuacji dziecka w teorii i praktyce pedagogiki stalinowskiej, w: Dziecko $w$ rodzinie $i$ w społeczeństwie. Dzieje nowożytne, pod red. K. Jakubiaka i W. Jamrożka, t. II, Wydawnictwo Uczelniane Akademii Bydgoskiej, Bydgoszcz 2002, s. $260-274$.

${ }^{28}$ K. Kosiński, Oficjalne i prywatne życie młodzieży w czasach PRL, Warszawa 2006, s. 233. Por. także: A. Walicki, Marksizm i skok do królestwa wolności, Warszawa 1996, s. 359.

${ }^{29}$ Dokumenty WKP (b) i rządu radzieckiego o szkole. Omawiam za: Źródła do dziejów..., s. 545-546.

${ }^{30}$ Cyt. Za: M. Heller, op. cit., s. s. 170-171. 
Wyeliminowanie rodziny i Kościoła ze struktury systemu instytucji wychowawczych stworzyło przestrzeń do realizacji szczególnego eksperymentu społecznego, jakim był projekt wychowania nowego człowieka - homo sovieticus. Wyjaśniając istotę tego nieludzkiego eksperymentu pedagogicznego, przeprowadzanego na dzieciach i młodzieży urodzonych i dojrzewających w ZSRR, Michał Kalinin ${ }^{31}$ stwierdził: powstaje u nas nowy człowiek socjalistycznego społeczeństwa. Temu człowiekowi należy wpajać najlepsze cechy ludzkie $e^{32}$. Proces wpajania wspomnianych cech był utożsamiany przez M. Kalinina $\mathrm{i}$ innych przedstawicieli komunistycznych władz Rosji sowieckiej z wychowaniem rozumianym jako określone, celowe i systematyczne oddziaływanie na psychikę wychowanka celem wszczepienia mu właściwości, których sobie życzy wychowawca ${ }^{33}$.

$\mathrm{Z}$ myślą o pomyślnym przebiegu tak rozumianego wychowania kierownictwo partii bolszewickiej już w pierwszych miesiącach po zdobyciu władzy w Rosji przyjęło i wdrożyło w życie założenie, zgodnie z którym w państwie komunistycznym wychowanie powinno być podporzadkowane zadaniom partii i państwa radzieckiego, bowiem podstawowym i głównym zadaniem wychowania komunistycznego [jest] udzielanie jak największej pomocy $w$ naszej walce klasowej ${ }^{34}$. W ten oto sposób wychowanie (urabianie) młodego pokolenia $\mathrm{w}$ ZSRR zostało $\mathrm{w}$ całości podporządkowane interesom partii komunistycznej.

\section{Organizacja Pionierska jako narzędzie ksztaltowania homo sovieticus}

Warunkiem pomyślnej realizacji procesu wychowania nowego człowieka (homo sovieticus) była intensywna indoktrynacja dzieci i młodzieży, rozciągnięta na wszystkie zakresy życia społecznego. Miała się ona dokonywać zarówno w szkole ${ }^{35}$, jak i w stworzonych po rewolucji i pieczołowicie kontrolowanych przez władze komunistyczne organizacjach: dziecięcej (Wszechzwiązkowej Organizacji Pionierskiej) i młodzieżowej (Wszechzwiązkowym Leninowskim Komunistycznym Związku Młodzieży - Komsomole).

Szczególną rolę w omawianym procesie miała odgrywać Organizacja Pionierska, niesłusznie marginalizowana $\mathrm{w}$ wielu dotychczasowych opracowaniach poświęconych tej problematyce. Tymczasem, biorąc pod uwagę wiek dzieci, które ogarniała ona swoimi wpływami (9-14 lat), jak i zakres jej wpływów, można uznać ją za jedno z najskutecz-

\footnotetext{
31 Jeden z członków kierownictwa Komunistycznej Partii Związku Radzieckiego (KPZR) w pierwszych dziesięcioleciach istnienia ZSRR.

32 M. Kalinin, Przemówienie na naradzie najlepszych nauczycieli szkół miejskich $i$ wiejskich, zwołanej przez redakcje czasopisma „Uczitelskaja Gazjeta” (20 XX 1938), w: M. Kalinin, O wychowaniu komunistycznym, Warszawa 1955, s. 47.

33 M. Kalinin, O wychowaniu komunistycznym, Referat wygłoszony na zebraniu aktywu partyjnego Moskwy, w: M. Kalinin, op. cit., s. 78-79.

34 Ibidem, s. 82.

35 Lapidarnie ujął to I. Kairow w podręczniku pt. Pedagogika (pod swoją redakcją): Szkoła radziecka powołana jest do ksztaltowania w swoich uczniach podstaw naukowego światopoglądu komunistycznego. Cyt. za: Pedagogika, pod redakcją I. Kairowa, t. II, Nasza Księgarnia, Warszawa 1950, s. 46.
} 
niejszych narzędzi wychowania nowego człowieka w ZSRR. Potwierdzeniem tego jest informacja zamieszczona na jednej z pierwszych stron Ksiegi przewodnika pionierskie$g o^{36}$, którą można uznać za podręcznik metodyki wychowania komunistycznego. Dowiadujemy się z niej, że Wszechzwiązkowa Organizacja Pionierska jest masowa komunistyczna organizacja dzieci w Zwiąku Radzieckim ${ }^{37}$, która ma wychowywać nieustraszonych, dzielnych, petnych radości życia, pewnych swojej sity, gotowych do przezwyciężania wszelkich trudności bojowników o wolność i honor naszej ojczyzny, o sprawe partii Lenina - Stalina, o zwycięstwo komunizmu ${ }^{38}$. Komunistyczne władze Rosji sowieckiej z dumą konstatowały, że w szeregach Organizacji Pionierskiej, dzieci wychowują się duchu komunizmu. Wyrastaja [...] na goracych patriotów radzieckiej ojczyzny, bezgranicznie oddanych sprawie Lenina - Stalina, na wykształconych, kulturalnych, aktywnych $i$ świadomych budowniczych, obywateli społeczeństwa komunistycznego ${ }^{39}$.

Przybliżając założenia programowe Organizacji Pionierskiej, należy podkreślić jej ścisłe zespolenie z Komsomołem (utworzonym w listopadzie 1918 r.). Głównym zadaniem Komsomołu było bowiem okazywanie czynnej pomocy partii bolszewickiej i rzadowi radzieckiemu w statym rozwijaniu i umacnianiu naszej szkoły, w systematycznym podnoszeniu poziomu nauczania uczniów, w wychowaniu uczacej się młodzieży [... $]^{40}$, a także $w$ ideologicznym urabianiu młodzieży pracujacej ${ }^{41}$. Jednym z najważniejszych zadań Komsomołu było kierowanie i nadzór nad działalnością Organizacji Pionierskiej².

Za początek Organizacji Pionierskiej uznaje się dzień 13 lutego 1922 r., kiedy to komsomolcy moskiewscy zorganizowali zbiórkę pierwszego zastępu pionierskiego, w której wzięło udział 52 dzieci $^{43}$. Wydarzenie to zapoczątkowało proces tworzenia kolejnych zastępów zarówno w Rosji, jak i innych republikach Związku Radzieckiego. Jednak oficjalnie Organizacja Pionierska powstała 19 maja 1922 r., w trakcie II Ogólnorosyjskiej Konferencji Rosyjskiego Komunistycznego Związku Młodzieży (RKZM). W trakcie V Zjazdu Komsomołu (w październiku 1922 r.) zastępy te połączono w jedną dziecięcą organizację komunistyczną ${ }^{44}$, a ponadto, nawiązując do myśli Lenina, określo-

\footnotetext{
${ }^{36}$ Księga przewodnika pionierskiego, Iskry, Warszawa 1952, s. 4. Z perspektywy dnia dzisiejszego Księge można uznać za wzorcowy podręcznik metodyki wychowania komunistycznego dzieci i młodzieży w wieku wczesnoszkolnym w ZSRR.

${ }^{37}$ Księga przewodnika pionierskiego, s. 7.

38 W. Mołotow, Trzydziestolecie Wielkiej Październikowej Rewolucji Socjalistycznej. Cyt. Za: Księga przewodnika pionierskiego, s. 32.

39 Księga przewodnika pionierskiego, s. 7.

40 A. Kurdiajew, Wydziat Pionierski Rejonowego Komitetu Komsomotu, Warszawa 1951, s. 3.

${ }^{41}$ S. Kaftanow, Komsomoł $w$ walce o przodująca naukę $i$ kulturę, Warszawa 1951, s. 3.

${ }^{42}$ O pełnej zależności organizacji pionierskiej od Komsomołu świadczy m.in. procedura usuwania dziecka - pioniera z organizacji pionierskiej. Każde postanowienie w tej sprawie musiało być zatwierdzone najpierw przez szkolny komitet Komsomołu, dyrektora szkoły oraz miejski lub rejonowy komitet Komsomołu. Por. Księga przewodnika pionierskiego, s. 39.

43 Ibidem, s. 10.

${ }^{44}$ A. Urban-Podolan, Organizacja pionierska, pionierzy w: Encyklopedia Dzieciństwa, http://encyklopediadzieicństwa.pl/index.php?title=Organizacja_pionierska, dostęp: 10. 12. $2016 \mathrm{r}$.
} 
no jej strategiczny cel, jakim był udział organizacji w zorganizowaniu, zjednoczeniu, wychowaniu i przygotowaniu mas ludowych do walki o interesy proletariatu ${ }^{45}$. Założenia ruchu pionierskiego z okresu rządów Lenina potwierdził kolejny Zjazd partii, odbywający się już pod przewodnictwem J. Stalina ${ }^{46}$.

W materiałach propagandowych poświęconych organizacji pionierskiej podkreślano jednak, że jej rodowód jest starszy i sięga okresu wojny domowej w Rosji. Eksponowano zwłaszcza dzień 25 maja 1919 r., w którym młodzież Moskwy obchodziła dzień powszechnego przysposobienia wojskowego ${ }^{47}$. Z tej okazji na Placu Czerwonym zgromadzono dzieci moskiewskie, które określały siebie zastępem młodych komunistów ${ }^{48}$. W skierowanym do nich przemówieniu W. Lenin stwierdził, że dzieci (dorastające pokolenie robotników) powinny pomagać rewolucji. Sformułował też tezę, w myśl której organizacja dziecięca to najlepsza szkoła wychowania komunistów. W innym wystąpieniu, kontynuując wątek komunistycznego wychowania młodzieży, Lenin stwierdził, iż przed każdym, kto wstąpił w szeregi Komunistycznego Związku Młodzieży, stoi zadanie dopomożenia partii $w$ budowie komunizmu $i$ dopomożenia całemu młodemu pokoleniu $w$ stworzeniu społeczeństwa komunistycznego ${ }^{49}$.

Śmierć Lenina [21 stycznia 1924 r.] stała się dla organizacji pionierskiej kolejną datą przełomową: w dniach oficjalnej żałoby państwowej, zgodnie z kształtującym się rytuałem państwa totalitarnego, kierownictwo Centralnego Komitetu Komsomołu złożyło przyrzeczenie partii komunistycznej i jej przywódcy, Stalinowi, że w organizacji pionierskiej wychowa godne pokolenie leninowców ${ }^{50}$. Równocześnie Plenum CK WLKZM postanowiło nadać organizacji pionierskiej imię Włodzimierza Lenina. Sam akt przyjęcia imienia Lenina przez organizację pionierów, datujący się na 23 maja 1924 r., miał miejsce w Moskwie, na Placu Czerwonym. Zgodnie z założeniami systemu tresury wydarzenie to miało bogatą oprawę propagandową. Jej kulminacją było złożenie przez 10 tysięcy pionierów przysięgi partii na wierność dziełu wielkiego wodza proletariatu ${ }^{51}$. Świadkami tego wydarzenia byli m.in. delegaci na zjazd partii bolszewików. Tak oto W. I. Lenin, zgodnie z zasadami tresury człowieka, stał się dla dziecięcego ruchu komunistycznego w Rosji wodzem, modelem, namiastką Boga, którego komuniści wyrugowali z przestrzeni wychowawczej.

$\mathrm{Na}$ autorytecie Lenina bazował jego następca - Józef Stalin. Z okazji pierwszej rocznicy śmierci Lenina zwrócił się on do społeczeństwa, w tym zwłaszcza do młodzieży, ze

${ }^{45}$ Księga przewodnika pionierskiego, s. 10.

${ }^{46}$ Należy podkreślić, że od pierwszych chwil swego istnienia organizacja pionierska stanowiła ona część składową Komsomołu, stąd traktowana była jako jego przybudówka.

${ }^{47}$ Księga przewodnika pionierskiego, s. 9.

48 Ibidem, s. 9.

49 Ibidem, s. 9. Przytoczone stwierdzenie oznaczało w praktyce, że Organizacja Pionierska, obok szkoły i Komsomołu, stała się w ZSRR jednym z najważniejszych narzędzi wychowania nowego człowieka - sztandarowego hasła i celu rewolucji bolszewickiej w Rosji.

50 Ibidem, s. 13.

51 Ibidem, s. 13. 
szczególnym apelem: Zachowujcie Iljicza w pamięci, kochajcie go, studiujcie dzieła Iljicza, naszego nauczyciela, naszego wodza. Walczcie przeciw wrogom wewnętrznym i zewnętrznym i zwyciężajcie ich - jak Iljicz. Budujcie nowe życie, nowy byt, nowa kulturę - jak Iljicz ${ }^{52}$. Uroczyste deklaracje przywódców organizacji pionierów mówiące o lojalności dzieci i młodzieży wobec Lenina nie mogły zmienić faktu, że organizacja pionierska praktycznie od oczątku swego istnienia pracowała zgodnie z mądrymi wskazaniami towarzysza Stalina ${ }^{53}$.

Sytuacja ta znalazła odzwierciedlenie w programie organizacji pionierskiej. Jego mottem przez pierwszych trzydzieści lat istnienia było hasło: Do walki o sprawe Lenina - Stalina bądź gotów ${ }^{54}$. Można je traktować jako uniwersalne zadanie, postawione przez przywódców państwa sowieckiego członkom tej masowej, komunistycznej organizacji dzieci, działającej praktycznie w całym okresie istnienia Związku Radzieckiego. Początkowo Organizacja Pionierska była organizacją dobrowolną, do której mogły należeć wszystkie dzieci od 9 do 14 roku życia. Jednak w miarę umacniania się stalinowskiej wersji państwa sowieckiego w coraz większym stopniu stawała się ona organizacją obowiązkową dla uczniów wspomnianej grupy wiekowej. Stąd też drużyny pionierskie tworzono zarówno w szkołach, jak i w domach dziecka, a także na obozach dziecięcych.

Procedura przyjmowania dziecka do organizacji pionierskiej była wielostopniowa. Kandydat na pioniera, który zapragnął wstąpić w jej szeregi, zawiadamiał o tym przewodniczącego rady albo przewodnika zastępu. Następnie ktoś z członków rady zaznajamiał nowo wstępującego z celami organizacji pionierskiej, z symbolami pionierskimi oraz z tekstem uroczystego przyrzeczenia. Wyjaśniał też przyszłemu pionierowi czekające go zobowiązania, informował, że pionier powinien się dobrze uczyć, być zdyscyplinowany, brać czynny udział w pracy swojego ogniwa i zastępu, a nade wszystko wszędzie $i$ we wszystkim służý za wzór innym dzieciom ${ }^{55}$.

Generalnie jednak od kandydata na pioniera nie wymagano spełnienia żadnych szczególnych warunków. Kwestia przyjęcia w szeregi organizacji nowego członka, który zaznajomił się już z symbolami pionierskimi i tekstem uroczystego przyrzeczenia, była rozstrzygana w jawnym głosowaniu na zbiórce zastępu. Nowo przyjęty uczeń niejako automatycznie zostawał włączony do jednego z ogniw. Jednak, aby zyskać pełnię praw, musiał on złożyć uroczyste przyrzeczenie. Z reguły przyrzeczenie składało kilku nowych pionierów, ustawionych podczas zbiórki w oddzielnym szeregu. W pierwszej kolejności nowo wstępujący głośno ,wygłaszali” przyrzeczenie, następnie każdy z nich podpisywał jego treść i przekazywał je przewodnikowi zastępu. Ten, po przyjęciu przyrzeczenia, zawiązywał pionierowi czerwoną chustę, wręczał znaczek i zwracał się do każdego z nowo przyjętych z hasłem pionierskim: „Do walki o sprawę Lenina - Stalina bądź gotów”. Nowo przyjęty odpowiadał na to: „Zawsze gotów” i salutował po pioniersku ${ }^{56}$.

\footnotetext{
52 J. Stalin, Dzieła, t. 7, Książka i Wiedza, Warszawa 1950, s. 25.

${ }^{53}$ Księga przewodnika pionierskiego, s. 14.

54 Ibidem, s. 38.

55 Ibidem, s. 37.

56 Ibidem, s. 38.
} 
Następnie stawał na lewym skrzydle zastępu pionierskiego. Odtąd też stawał się pełnoprawnym członkiem organizacji pionierskiej.

Kilka słów warto też poświęcić strukturze Organizacji Pionierskiej. Jej podstawową jednostką była drużyna pionierów, która dzieliła się na zastępy, te zaś na ogniwa ${ }^{57}$. Drużynę pionierską można było utworzyć w szkole lub domu dziecka wtedy, gdy skupiała ona więcej niż 30 pionierów. Do zadań drużyny należało urządzanie przeglądów działalności zastępów pionierskich, pokazów kółek przedmiotowych, twórczości artystycznej, zawodów sportowych, wystaw prac pionierskich z zakresu techniki, sztuk plastycznych, wystaw gazetek ściennych. Ponadto drużyna przeprowadzała uroczyste zbiórki z okazji świąt rewolucji. Przywilejem drużyny pionierskiej było też rekomendowanie przyjęcia najlepszych pionierów (którzy ukończyli 14 lat) w szeregi Komsomołu ${ }^{58}$. Każda drużyna wydawała własną gazetkę ścienną. Swoje zbiórki drużyna organizowała raz na 2-3 miesiące.

Na czele drużyny pionierskiej stała rada (licząca od 7 do 15 osób) wybierana przez członków drużyny w głosowaniu jawnym. Formalnie rada kierowała pracą drużyny, w rzeczywistości za jej działalność odpowiadał przewodnik drużyny, który nie był wybierany przez radę, lecz mianowany przez Wydział Pionierski Komsomołu. Każda drużyna pionierska miała swój sztandar, a każdy z zastępów swój proporczyk, fanfary $\mathrm{i}$ werble. Były one przechowywane w izbie pionierskiej. Zgodnie z zasadami tresury drużynom pionierskim nadawano imię jakiegoś znakomitego działacza partii bolszewickiej, uczonego, bohatera Związu Radzieckiego lub Bohatera Pracy Socjalistycznej59. Celem przyciągnięcia do drużyny pionierskiej jak największej liczby uczniów drużyny pionierskie (we współpracy z nauczycielami) tworzyły w szkołach rozmaite kółka - krajoznawcze, przyrodnicze, radiowe, modelarskie, artystyczne, sportowe i inne.

Częścią składową drużyny był zastęp pionierski, który z reguły obejmował pionierów jednej lub dwóch klas równoległych. Zastęp dzielił się na ogniwa. Zgodnie z treścią Księgi przewodnika pionierskiego to w zastępie odbywała się zmasowana indoktrynacja pionierów. W trakcie zbiórek organizowano dla nich pogadanki o partii bolszewickiej oraz o Komsomole, zaznajamiano z biografiami wodzów rewolucji (Lenina i Stalina), a także pionierów, którzy w bohaterski sposób zapisali się w krótkiej historii ZSRR. W zastępie organizowano też zbiórki związane z obchodami świąt rewolucyjnych i urządzano seanse filmowe, w trakcie których wyświetlano pionierom starannie dobrane filmy propagandowe. Seanse filmowe łączono z dyskusją (częściej prelekcją) na tematy poruszane w filmach. Zastęp organizował także różnego rodzaju gry polowe, zawody sportowe oraz wydawał gazetkę ścienną. Zbiórkę zastępu przeprowadzano średnio raz w miesiącu.

Pracą zastępu, podobnie jak w przypadku drużyny, kierował (mianowany przez Komsomoł) przewodnik zastępu oraz rada zastępu, składająca się z 5-7 osób, wybierana

\footnotetext{
57 Ibidem, s. 32.

58 Ibidem, s. 32-33.

59 Ibidem, s. 33.
} 
w głosowaniu jawnym na okres jednego roku ${ }^{60}$. Przewodnik, choć nie był wybierany do rady zastępu, wchodził w jej skład z urzędu. Zastępom pionierskim, tak jak drużynom, Komitet Komsomołu mógł nadawać imiona wybitnych działaczy partii bolszewickiej, wielkich dowódców, uczonych lub Bohaterów Pracy Socjalistycznej. Decyzje w tej sprawie ogłaszano zastępowi na specjalnie w tym celu zwołanej zbiórce.

Znamienny dla charakteru Organizacji Pionierskiej był propagandowy wymiar funkcjonowania drużyny lub zastępu. Odzwierciedleniem tego była m.in. procedura wyboru członków rady: w pierwszej kolejności wybierano tu przewodniczącego oraz redaktora gazetki ściennej. Szczególna troska o gazetkę ścienną i przekazywane przez nią informacje oraz komentarze o zabarwieniu ideologicznym i politycznym potwierdza, że cała Organizacja Pionierska traktowana była przez władze ZSRR jako narzędzie indoktrynacji młodego pokolenia.

Najmniejszym elementem struktury organizacyjnej Organizacji Pionierskiej było ogniwo. Obejmowało ono 8-10 pionierów jednego zastępu. W ogniwie miała przebiegać codzienna praca pionierska. W trakcie (regularnych) zbiórek pionierzy - członkowie ogniwa - mieli zajmować się pracą społecznie użyteczną, którą byli w stanie wykonać, organizować wycieczki po okolicy, czytać książki, czasopisma dziecięce i młodzieżowe, dyskutować nad przeczytanymi artykułami, organizować gry i zawody sportowe. Ponadto pionierzy należący do ogniwa mieli kontrolować postępy w nauce kolegów i organizować pomoc w przypadku napotkanych przez nich trudności.

Formalnie pracą ogniwa kierował ogniwowy. Kierownictwo organizacji pionierskiej zalecało, by był to pionier dzielny, energiczny, który dobrze się uczy, jest zdyscyplinowany, cieszy się szacunkiem kolegów i który potrafi zorganizować pracę i pociagnać za soba pozostałych pionierów ogniwa ${ }^{61}$. W rzeczywistości za działalność ogniwa odpowiadał przewodnik zastępu. Obowiązkiem każdego ogniwa pionierskiego było prowadzenie dziennika, w którym zamieszczano listę pionierów - członków ogniwa, plany pracy, uwagi pionierów na temat prac społecznych wykonywanych przez ogniwo, a także przejawy twórczości artystycznej pionierów, np. napisane przez nich wiersze.

Organizacja pionierska, podobnie jak Komsomoł, miała swoje symbole. Wśród nich szczególne miejsce zajmowała czerwona chusta pionierska, którą każdy pionier zobowiązany był stale nosić - w szkole, w domu, na ulicy. Zobowiązany był też strzec czerwonej chusty. Jej symbolika była na wskroś przesiąknięta ideologią komunistyczną. Czerwony kolor chusty, nawiązujący do czerwonego sztandaru Armii Czerwonej, symbolizował krew tysięcy bojowników powieszonych i rozstrzelanych przez obszarników i kapitalistów $^{62}$. Stąd też upominano pionierów: Noście ze czcia tę czerwona chustę, mocno trzymajcie $w$ dłoniach czerwony sztandar komunizmu ${ }^{63}$. Z kolei trzy końce chusty pionierskiej symbolizowały łączność trzech pokoleń: komunistów, komsomolców i pionierów. Na kanwie tego symbolu sformułowano zobowiązanie pionierów do walki o rewolucyjne

\footnotetext{
60 Ibidem, s. 34.

61 Ibidem, s. 34.

62 Ibidem, s. 45.

${ }^{63}$ Ibidem, s. 45.
} 
tradycje bolszewików z pokolenia Lenina, o sprawe naszej wielkiej proletariackiej, komunistycznej partii ${ }^{64}$.

Nakazu strzeżenia czerwonej chusty kierownictwo organizacji pionierskiej nie ograniczało do jej prania i prasowania. Pionierom wyjaśniano, że strzec jej to znaczy uczciwie wypełniać przykazania Lenina: dobrze się uczyć, być dobrym kolegą, pomocnikiem dorosłych w ich pracy, być wiernym, prawdziwym patriotą. Po II wojnie światowej siłę przekazu wspomnianego symbolu wzmacniano, odwołując się do bohaterskich czynów pionierów z czasów wojny ZSRR z Niemcami hitlerowskimi.

Kolejnym, ważnym symbolem organizacji pionierskiej była odznaka pionierska czerwona, pięcioramienna gwiazda o promieniu $1,5 \mathrm{~cm}$. Nad gwiazdą unosiły się trzy języki żółtych płomyków, które nawiązywały do wspomnianego już związku trzech pokoleń: komunistów, komsomolców i pionierów. Dwa dolne końce gwiazdy opasane były białą wstążką z napisem „Zawsze gotów”. W górnej części odznaki wyryty był sierp i młot - symbole ZSRR ${ }^{65}$.

Organizacja pionierska miała także swój salut - pozdrowienie pionierskie. Było to pięć palców prawej ręki, ściśle złączonych, uniesionych nad głową ${ }^{66}$. Pionierzy byli zobowiązani do salutowania przy spotkaniu z innym pionierem, $\mathrm{z}$ przewodnikiem, gdy zwracali się do dorosłych, gdy spotykali wojskowego, a także podczas słuchania hymnu ZSRR i Międzynarodówki. Ponadto zobowiązani byli do salutowania przy mauzoleum Lenina oraz przed każdym pomnikiem Lenina.

Znaczącym elementem symboliki organizacji pionierskiej był mundur, składający się z białej koszuli lub bluzki oraz ciemnych spodni lub spódniczki. Na głowie pionier nosił pilotkę lub beret (barwy ciemniej lub ochronnej), na szyi zaś wspomnianą już czerwoną chustę (zawiązaną pod kołnierzykiem). Na bluzie pionier nosił odznakę pionierską. Na lewym rękawie, powyżej łokcia, naszyte były specjalne naszywki - odznaki przewidziane dla członków i przewodniczących rad drużyn i zastępów oraz dla ogniwowych. Pionier zakładał mundur, uczestnicząc w zbiórce, zlocie, paradach i demonstracjach ${ }^{67}$.

Ważną rolę w funkcjonowaniu drużyny pionierskiej odgrywały fanfary i werbel. Fanfary służyły do zwoływania pionierów, przekazywania rozmaitych sygnałów i rozkazów $^{68}$, granych przez trębacza na polecenie przewodnika albo przewodniczącego rady zastępu czy drużyny. Natomiast werbel był wykorzystywany podczas udziału drużyny w pochodach, marszach i demonstracjach.

$* * *$

Zarysowana geneza oraz elementy struktury i symboliki Organizacji Pionierskiej ukazują, jak w warunkach państwa totalitarnego wynaturza się charakter instytucji społecz-

\footnotetext{
64 Ibidem, s 45.

65 Ibidem, s. 48.

66 Ibidem. S. 48.

${ }^{67}$ Ibidem, s. 48.

${ }^{68}$ Trębacz winien był umieć grać takie sygnały, jak: uwaga, zbiórka, wstawać, obiad, spotkanie, alarm, spać, odwołanie, podniesienie sztandaru, wyruszamy w pochód.
} 
nych. Stają się one konstruktami fasadowymi, które pod szyldem znanych i akceptowanych haseł programowych skrywają starannie dopracowane elementy systemu zniewalania jej członków, a w szerszej perspektywie członków całego społeczeństwa. Filozofia kłamstwa, charakterystyczna dla państw totalitarnych, znajduje pełne odzwierciedlenie w programie Organizacji Pionierskiej. Została ona bowiem stworzona przez przywódców rewolucji bolszewickiej w Rosji z myślą o urzeczywistnianiu lansowanych przez siebie celów ideologicznych i politycznych. W sferze społecznej wyrażały się one w dążeniu do wychowania nowego człowieka, który w przyszłości miał stać się homo sovieticus - wyższą formą homo sapiens.

Realizując wytyczone cele, komunistyczne władze ZSRR nie zawahały się sięgnąć po dzieci, które potraktowały jak tworzywo, surowiec, z którego zamierzały stworzyć wspomnianego homo sovieticus. Dla własnych celów wykorzystały też naturalną dla dzieci w wieku szkolnym potrzebę przebywania w gronie rówieśników, dążność do przeżywania przygód, poznawania środowiska, a także służby ojczyźnie i osobom potrzebującym pomocy. Wspomniane prawidłowości rozwojowe, znajdujące odzwierciedlenie m.in. w skłonności dzieci do zrzeszania się w mnie lub bardziej oficjalnych związkach i organizacjach dziecięcych i młodzieżowych, posłużyły komunistycznym władzom Rosji bolszewickiej do wciągnięcia w struktury sytemu urabiania ideologicznego młodego pokolenia milionów dziewcząt i chłopców. Niezwykle ważnym składnikiem tego systemu była Organizacja Pionierską, która odwołując się zarówno do potrzeb dzieci, jak i szczytnych haseł i ponadczasowych wartości, poddawała jej członków, pionierów, metodycznej indoktrynacji przyjmującej postać tresury.

Warto zauważyć, że w warstwie zewnętrznej Organizacja Pionierska nawiązywała do skautingu. Jednak podobieństwo to było pozorne, skauting bowiem stawiał na rozwój swoich członków, wyrabiał u chłopców „dzielny charakter” oraz zwracał uwagę na rozwijanie szlachetnych dążeń i dobrych przyzwyczajeń ${ }^{69}$. Organizacja Pionierska zaś przygotowywała swoich członków (chłopców i dziewczynki) do tego, aby w przyszłości stali się godną zmianą komsomolców i członków partii. Powodem do dumy było to, że pomagała ona partii i Komsomołowi urabiać, i indoktrynować dzieci radzieckie w duchu komunistycznym ${ }^{70}$.

\section{Bibliografia}

Grzybowski R., Podmiot czy tworzywo? Kilka uwag o sytuacji dziecka w teorii i praktyce pedagogiki stalinowskiej, w: Dziecko w rodzinie $i$ w społeczeństwie. Dzieje nowożytne, pod red. K. Jakubiaka i W. Jamrożka, t. II, Wydawnictwo Uczelniane Akademii Bydgoskiej, Bydgoszcz 2002.

${ }^{69}$ SCOUTING jako system wychowania młodzieży. Na podstawie dzieła Gienerała Baden-Powella przedstawił Andrzej Małkowski, Oficyna Wydawnicza Impuls, Kraków 2017. Reprint wydania z 1911 r., s. 14.

${ }^{70}$ Księga przewodnika pionierskiego, s. 8. 
Grzybowski R., U podstaw ksztaltowania się totalitarnego systemu wychowania i opieki nad dzieckiem i rodzina $w$ Polsce $w$ latach 1945-1956, „Studia i Badania Naukowe. Pedagogika” R. II, nr 2, Gdańsk 2008.

Grzybowski R., O wychowaniu w duchu moralności komunistycznej w ujęciu pedagogiki stalinowskiej oraz o niektórych metodach jej realizacji, w: Człowiek Idea Dzieło. Prace dedykowane Profesor Stefanii Walasek, red. B. Jędrychowska, Wydawnictwo Chronicon, Wrocław 2013

Heller M., Maszyna i śrubki. Jak hartowat się czlowiek sowiecki, Instytut Literacki, Paryż 1988.

Heller M., Niekricz A., Utopia władzy. Historia Zwiazku Sowieckiego. Od narodzin do wielkości 1917-1939, Wyd. Zysk S-ka, Poznań 2016, s. 13.

Kairow I., Pedagogika (pod swoją redakcją): Szkoła radziecka powołana jest do ksztattowania w swoich uczniach podstaw naukowego światopogladu komunistycznego. Cyt. za: Pedagogika, pod redakcją I. Kairowa, t. II, Nasza Księgarnia, Warszawa 1950.

Kalinin M., Przemówienie na naradzie najlepszych nauczycieli szkół miejskich $i$ wiejskich, zwołanej przez redakcje czasopisma „Uczitelskaja Gazjeta” (20 XX 1938), w: M. Kalinin, O wychowaniu komunistycznym, Warszawa 1955

Księga przewodnika pionierskiego, Iskry, Warszawa 1952.

Lenin W., Zadania związków młodzieży. Przemówienie wygłoszone na III Ogólnorosyjskim Zjeździe Komunistycznego Związu Młodzieży Rosji, 2 października 1920 roku, w: Źródła do dziejów wychowania i myśli pedagogicznej, t. III, Warszawa 1966.

Kaftanow S., Komsomot w walce o przodująca nauke i kulturę, Warszawa 1951.

Kosiński K., Oficjalne i prywatne życie młodzieży w czasach PRL, Warszawa 2006, s. 233.

Kurdiajew A., Wydziat Pionierski Rejonowego Komitetu Komsomolu, Warszawa 1951.

Mazur M., O człowieku tendencyjnym... Obraz nowego człowieka w propagandzie komunistycznej w okresie Polski Ludowej i PRL 1944-1956, Wyd. UMCS, Lublin 2010.

Mołotow W., Trzydziestolecie Wielkiej Październikowej Rewolucji Socjalistycznej. Cyt. Za: Ksiega przewodnika pionierskiego.

Muszyński H., Poglady Lenina na wychowanie i ich znaczenie dla rozwoju socjalistycznej pedagogiki, „Nauczyciel i Wychowanie” 1970, nr 3/65.

Souvarine B., Aveux a Moscou, „La Vie Intelectuelle”, Paryż 10.04.1038. Cyt. Za: M. Heller, A. Niekricz, Utopia władzy. Historia Zwiazku Sowieckiego. Od narodzin do wielkości 1917-1939, Wyd. Zysk S-ka, Poznań 2016.

Stalin J., Dzieła, t. 7, Książka i Wiedza, Warszawa 1950.

Urban-Podolan A., Organizacja pionierska, pionierzy w: Encyklopedia Dzieciństwa, http://encyklopediadzieicństwa.pl/index.php?title=Organizacja_pionierska, dostęp: 10. 12. $2016 \mathrm{r}$.

Walicki A., Marksizm i skok do królestwa wolności, Warszawa 1996.

Wiloch T., System wychowawczy a socjalizm w ujęciu Lenina, „Nauczyciel i Wychowania” 1970, $\mathrm{nr} 2(64)$.

Źródla do dziejów wychowania i myśli pedagogicznej, t. III, Warszawa 1965. 
